\title{
한국의 ODA 철학 및 기본 정책문서 정책토론회
}

정리 : KOICA 정책연구실

I. 개요

기본 철학(주동주 KIET박사)

- 일 시: 2007. 10. 12 (금) 15:00 18:00

- 장 소: 외교부 17 층 상황실

III. 토론회 내용

- 참 석: $\mathrm{ODA}$ 관련 학계 - 시민단체 - 연구기관 전문가 25 명

\section{1. 필요성 및 총론적 견해}

- 참석자 공히 $\mathrm{ODA}$ 철학의 정립 및 기본 정책

II. 진행 문서 수립의 필요성에 대하여 공감

- 모두 발언: 박인국 다자외교실장

- 다만 ODA 철학에 대하여 시민단체 측에서는

- ODA정책문서의 필요성 및 최근 개발협력 분 야의 국제적 동향과 과제 설명

- 사 회: 박강호 개발협력정책관

- 발 제:

- 발제 1: 한국 ODA 철학 및 기본 정책문서 수 립방안(전승훈 개발전략연구소장) 원조의 순수성 및 보편적 가치(universal value)을 적극 주장한 반면, 일부 전문가는 이 것이 정부의 정책문서이니만큼 납세자를 설득 할 수 있는 국가적 이익이 포함되어야 하며, 대외원조는 외교정책의 핵심부문(integral part)이 되어야 한다는 상반된 견해가 제시

- 발제 2: 국제개발협력에서의 한국의 역할과 


\section{ODA 철학 및 이념적 기초}

- 발제안은 한국이 ODA를 하여야 하는 이유로 서 아래와 같은 이념적 근거 및 $\mathrm{ODA}$ 의 목적 을 제시

- 한민족의 개국이념인 홍익인간이 $\mathrm{ODA}$ 의 정신

- 헌법상 기본 목적인 "항구적인 세계평화와 인 류공영에 이바지"함으로써 “우리들과 우리들 자손의 안전과 자유와 행복을 영원히 확보”에 기여

- 그 이외 인도적 책무 및 외교 정책적 목적, 한 국이 대외교역 및 동북아 안정에 생존기반을 두고 있는 여건에서 국가적 이익에의 기여 필 요성

- 한국의 ODA는 국제사회의 핵심과제인 "빈곤 완화”에 초점을 두고, 또한 한국이 개도국과 의 같은 여건에서 출발하여 발전을 이룬 역사 적 배경을 감안, "동반자" 의 개념을 포괄

- 동 발제에 대해 아래와 같은 참석자 의견이 제시

- "홍익인간" 의 이념은 우리 민족의 이념은 될 수 있으나 글로벌 시대의 보편적 이념이 될 수 없으니 부적합

- 우리 원조이념에 국익을 명시적으로 규정하 여 우리 대외원조의 순수성을 훼손하는 것은 바람직하지 않음

- 그러나 원조이념은 정부의 정책지침인 바, 납
세자를 설득할 수 있는 국가이익의 개념은 명 시적으로 나타나지는 않더라도 반드시 기저 에 녹아 있어야 한다는 견해 강력히 개진

- ODA 목적으로 “빈곤” 보다 보다 폭 넓은 가치 가 추구되는 것이 바람직: Right-based approach, 인권, 안전, 환경, 성차별 방지 등 을 포괄

\section{ODA 원칙}

- 발제안은 다음과 같은 7 개 원칙을 제안 - 인간역량 개발의 중시, 수원국의 Ownership, 개도국 민간부문 개발지원, 한국적 경 험과 전문성 발휘, 국제사회의 협력과 연대, 관련 정책과의 유기성 유지, 민간의 적극적 참여

- 이에 대하여 참석자들은 다음과 같은 의견이 제시

- 정책의 융통성을 부여하고 원칙의 단순화를 위해 원칙(Principle)은 4-5개로 축소조정하 는 것이 바람직

- 하나의 의견은 "한국적" 이라는 것을 내세우 는 것은 바람직하지 않다는 의견

- 다른 하나는 실제 개도국에서 한국의 경험에 대한 수요가 매우 강하다는 점을 역설

* 지난 3월 $\mathrm{ODA}$ 컨퍼런스에서 제프리삭스 교수도 한국이 한세대(一世代)에 이룬 발전경험은 유래를 찾기 어려우며 개도국에 모범적 text가 될 것임을 역설 
- $\mathrm{NGO}$ 의 역할이 우리 ODA정책에서 중요하게 고려될 수 있도록 원칙에서 확고히 하는 것이 필요

\section{4. 정책 지침(Policy Guideline)}

- 발제안은 다음과 같은 7 개 지침을 제안: 원조 의 규모, 내용, 사업수행방식, 지역별 배분기 준, 다자협력, 해외재난구호, 홍보와 교육

- 정부에 정책적 융통성을 부여하는 취지에서 기준을 간결하게 하는 것이 바람직하다는 의견

\section{5. 운영 체계}

- 발제안은 실제의 운영절차 및 체계에 관한 규 정으로 다음 5 개 기준을 제시: 중장기 전략 수 립, Country Programming 운영, 정책운영 의 조화, 투명성, 평가체계

- 정책의 융통성을 부여하는 의미에서 다소간
조정하는 것이 바람직하다는 일부 의견 제시

- 무상, 유상기관의 통합, 집행체제의 단순화, 원조정책 수립 및 집행과정의 효율화가 필요 하다는 의견 제시

\section{$\mathrm{IV}$. 논의기조와 결어}

- 특히 $\mathrm{ODA}$ 의 철학 및 이념적 기초에 있어서 글로벌 보편성과 원조의 순수성을 강조하는 시민단체의 의견과 본 문서가 정부의 정책지 침으로서 납세자를 설득할 수 있어야 하는 것 이므로 국가적 이익이 명시적으로는 아니라도 기저에 포함되어 있어야 한다는 견해가 대립

- $\mathrm{ODA}$ 의 철학의 정립과 기본 정책문서를 수립 하는 일에 대하여서는 정부와 학계, 시민사회 가 함께 노력하여야 하며, 정부의 주요 외교정 책의제로 발전시켜야 한다는데 참석자 모두 동의 